\title{
Comparison between the effects of group-based acceptance and commitment therapy and group-based reality therapy on work-family conflict \& psychological well-being of married female staffs
}

\author{
Hajikaram A ${ }^{1}$,Ghamari $\mathbf{M}^{2}$,Amiri Majd $\mathbf{M}^{3}$ \\ 1. Department of Counseling, Abhar Branch, Islamic Azad University, Abhar, Iran. ORCID ID: 0000-0001-6090-1036 \\ 2. Department of Counseling, Abhar Branch, Islamic Azad University, Abhar, Iran (Corresponding Author), Tel: +98-2632548061, Email: \\ ghamari.m@abharian.ac.ir, ORCID ID: 0000-0003-0913-5561 \\ 3. Department of counseling, Abhar Branch, Islamic Azad University, Abhar, Iran
}

\begin{abstract}
Background and Aim: Administration of the therapy protocols can increase psychological well-being with resultant decrease in the work-family conflict. The purpose of this study was to make a comparison between the effects of group-based acceptance and commitment therapy and group-based reality therapy on work-family conflict and psychological well-being with maintenance effect among married female tele-communication company staffs in Tehran, in 2018-2019.
\end{abstract}

Materials and Methods: This was a semi-experimental study with pre-test, post-test and follow-up design. 45 employees were selected purposefully and randomly were assigned to three groups. For data collection we used work-family questionnaire (Netemeyer, Boles \& McMurrian, 1996) \& psychological well-being scale (Ryff, 1989) and two therapeutic protocols (group-based acceptance and commitment therapy and group-based reality therapy). We used mix variance analysis and frequency measurement variance analysis.

Results: Comparison of the effects of group therapy with acceptance and commitment therapy with those of group-based reality therapy showed different results on reduction of work-family conflict. Also in regard to positive relationships with others (psychological wellbeing), acceptance and commitment therapy showed different efficacy compared to group therapy based on reality.

Conclusion: We concluded that group-based acceptance \& commitment therapy can be used for improvement of the psychological well-being, and group-based reality therapy can be a suitable way for reduction of the work-family conflicts.

Keywords: Acceptance and commitment therapy, Reality therapy, Work-family conflict, Psychological well-being, Married female employee

Received: May 5, $2019 \quad$ Accepted: May 28, 2019

How to cite the article: Hajikaram A, Amiri Majd M, Ghamari M. Comparison between the effects of groupbased acceptance and commitment therapy and group-based reality therapy on work-family conflict \& psychological well-being of married female staffs. SJKU 2019; 24(3): 20-33. 


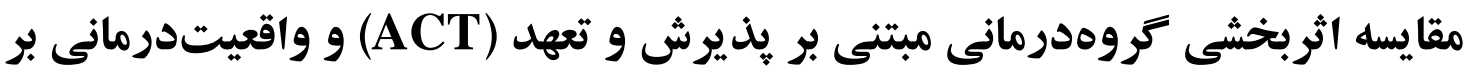 تعارض كار - خانواده و بهزيستى روانى زنان متاهل شاغل با اثر ماند كارى}

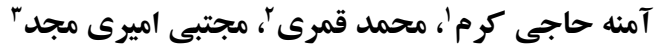

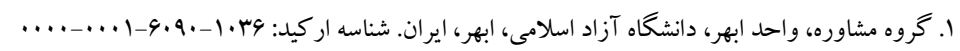

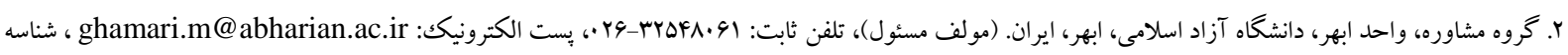

زمينه و هدف: با اجراى يروتكلهاى درمانى مى توان بهزيستى روانى را افزايش و تعارض كار - خانواده را كاهش داد. از اين رو

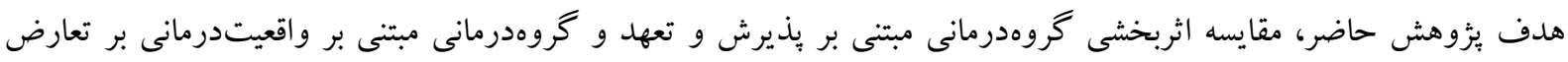

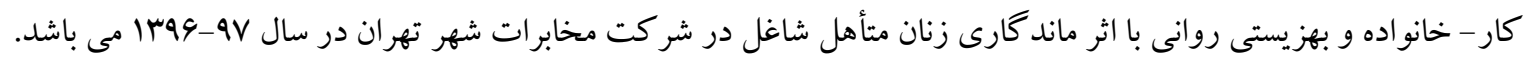

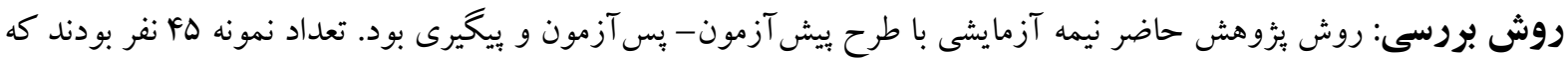

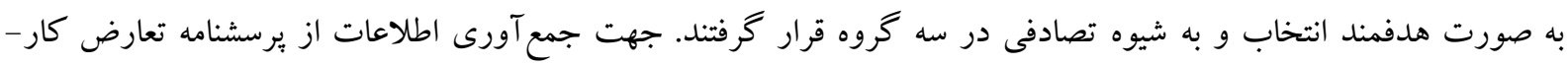

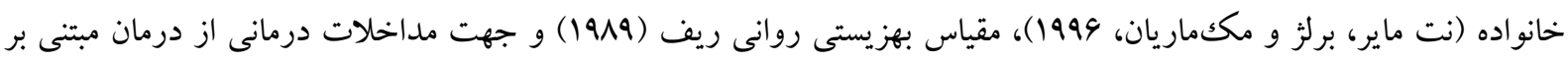

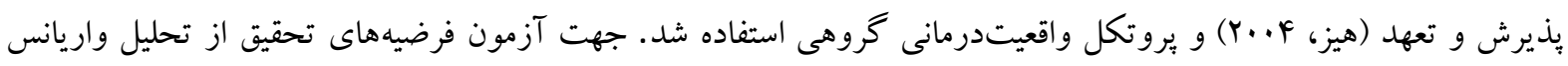
آميخته و تحليل واريانس اندازه گيرى وهاى مكرر استفادهشد.

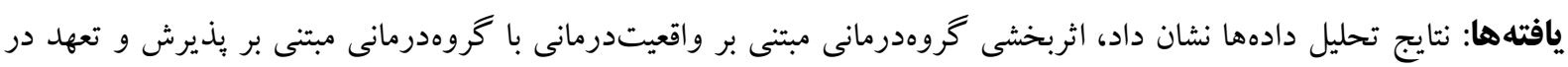

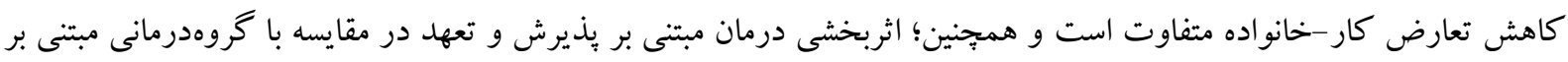

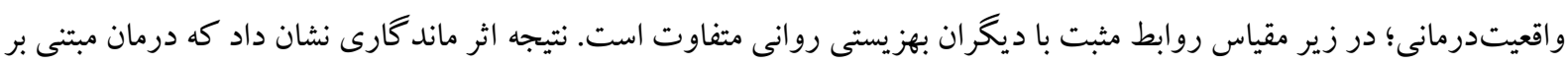

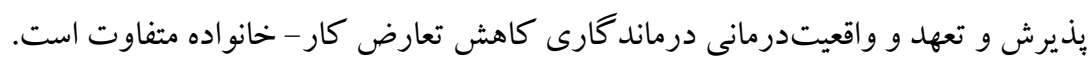

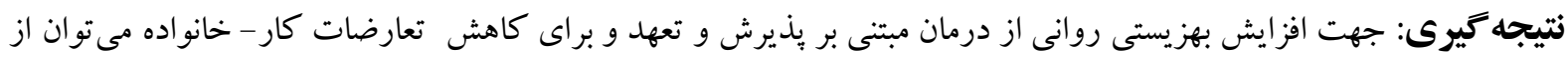
مداخلات مبتنى بر واقعيتدرمانى استفاده كرد. كليد وازه ها: درمان مبتنى بر يذيرش و تعهد، واقعيتدرمانى، تعارض كار - خانو اده، بهزيستى روانى، زنان متأهل شاغل

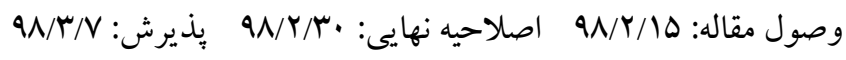


كفت كه بهزيستى روانى شامل دريافـتهـاى فرد از ميزان هماهنكى بين هدف هاى معين و ترسيم شـده بـا بيامـدهاى مقدمه

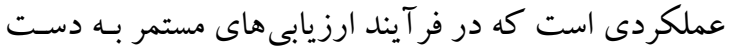

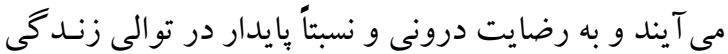

منتهى مى شوند (9). درمان مبتنى بر يذيرش و تعهد از جمله رويكردهـايى است

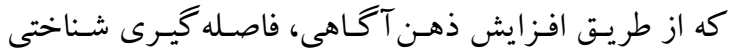
(مشاهده افكار)، ايجاد تعهد نسبت بـه در گيرى فعالانه در جهان خارجى و تـلاش بـراى دسـتــابى بـه يكك زنـدگى يرمعنا و اصيل با هدف افزايش انعطاف يذيرى روانشـناختى

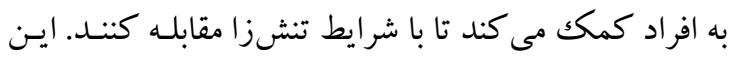
رويكرد درمانى داراى شش فرايند مركزى مى باشـد كـه در

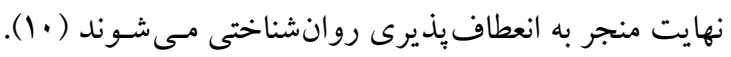

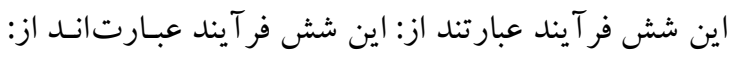

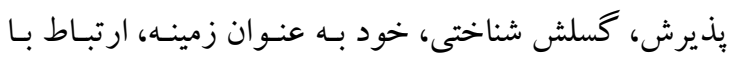

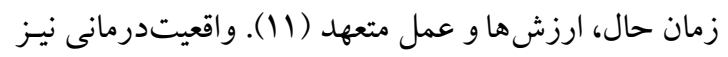

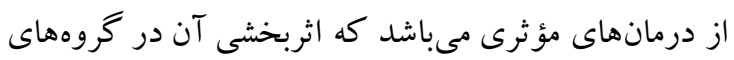

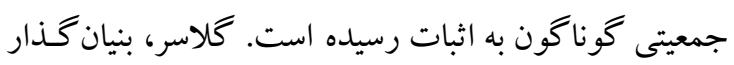
اين رويكرد، معتقد است هر فردى هويتى دارد كه به وسيله

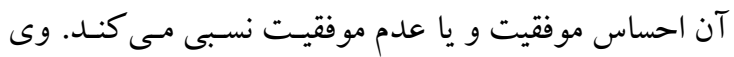
هويت را آن تصويرى مىداند كه فرد از خود دارد. هويت-

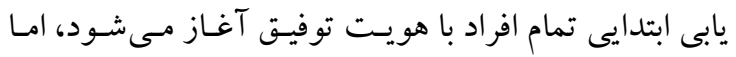

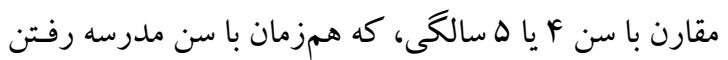

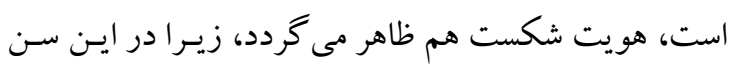

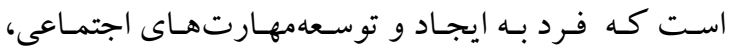

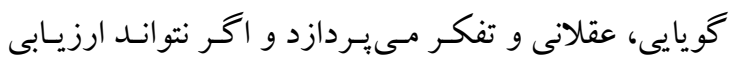

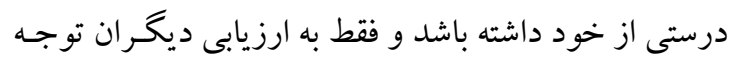

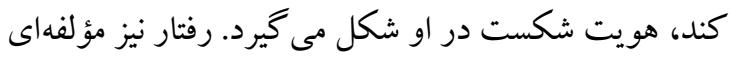

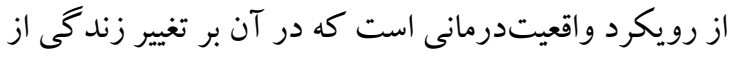
طريق تغيير رفتار تأكيـد مسى شـود و بيمـاران بايـــ تشـخيص دهند كه جهـ رفتارهـايى بـراى آنها مؤثر و جـه رفتارهـايى زيانبخش هستند؛ اين امر به معناى كشف كليـت رفتـا مـى باشد (Y) (I).

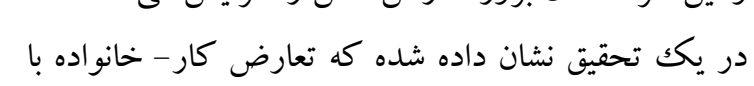
كاهش رضايت شغلى و زناشويى همراه است (F). همجِين

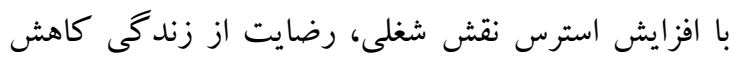

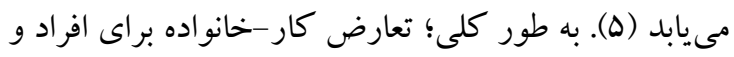
سازمان به يك اندازه اهميت دارد. زيرا تعارض، براى افراد بهعنوان منبع اصلى استرس يا ييامدهاى منفى از جمله

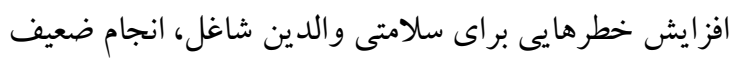
وظايف والدينى و همسرى، بدخلقى، كاهش رضايت از

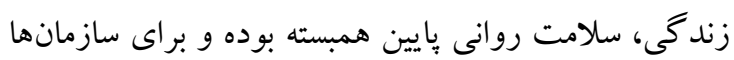

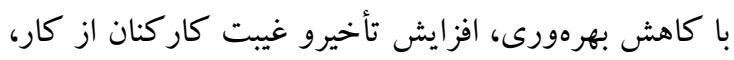

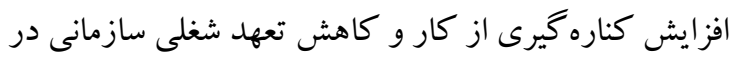
يى خواهد داشت (9).

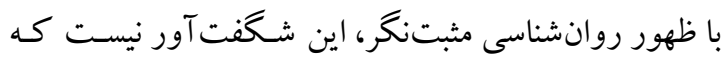
جنبههاى مثبت بهداشت و سلامت در روانشناسى سـلامت

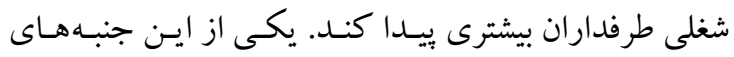

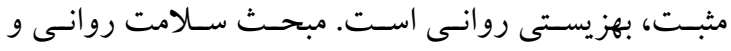
بهزيستى روانى در دو دهه اخير در ادبيات يزوهشى به وفور

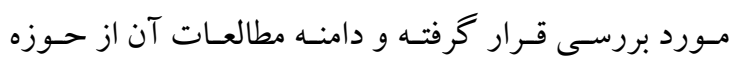

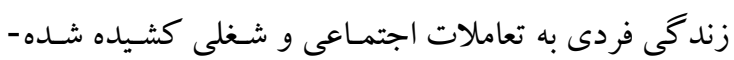
است (V). در راستاى تعريـف ايسن سـازه مفهومى (^) بايـد 


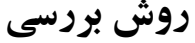
نوع مطالعه و نمونه كيرى

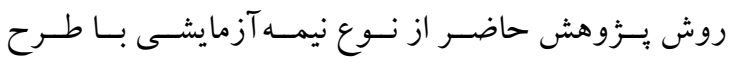

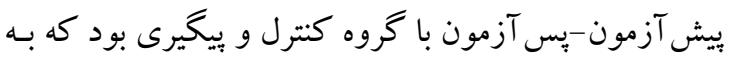

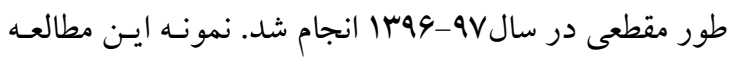

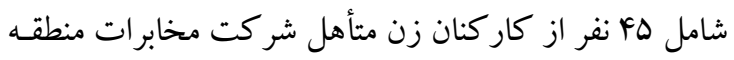

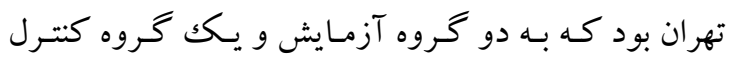

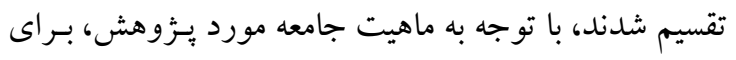

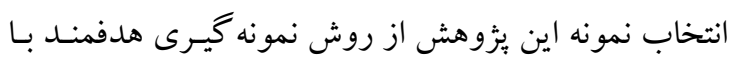

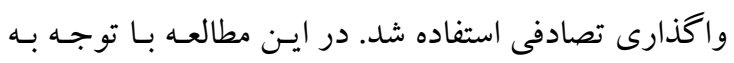

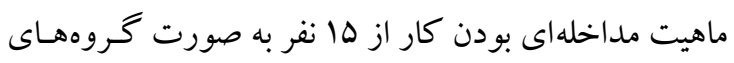
برابر همتاسازى استفاده شده است. البته مسى توان در خنين

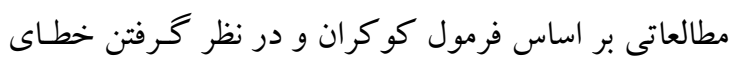

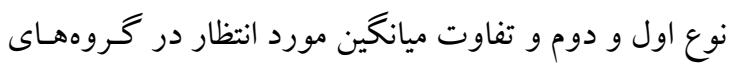

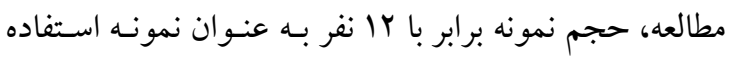

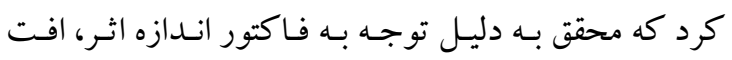

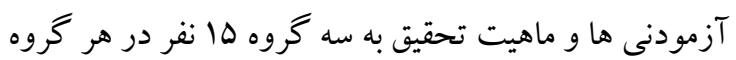
را انتخاب كرده است. از جمله رعايـت ملاحظـات اخلاقى در اين مطالعه مى تـوان بـه محرمانسه بـودن نـام و اطلاعـات

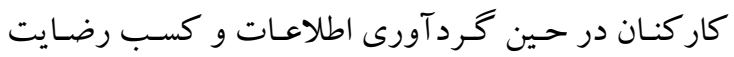
شخصى آنها جهت مشاركت در اين يزوهش را نام بـرد. در يثزوهش حاضر از ابزارهاى زير استفاده شده است:

\section{مقياس بهزيستى روانى ريف}

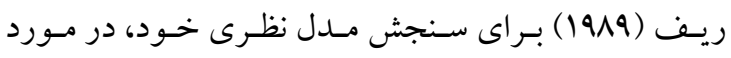

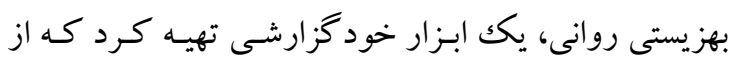
مهم ترين سنجههاى بهزيستى روانى بهشمار مىرود. نخستين

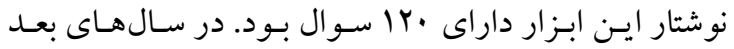
براساس بزّوهشهايى كه روى ويز گیىهـاى روانسـنجى آن

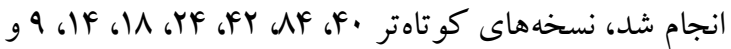
r سئو الى تدوين شد. ريف خود معتقد است كه نسخهى NF سئو الى آزمون در مقايسه با ساير نوشتارها قابليت بيشترى در تعيين وضعيت بهزيستى روانى دارد. او نسخه مA سـوالى را در سال 1919 تدوين نمود. در نوشتار \&Aه سوالى براى هر
تحقيقات گوناكونى بهصورت جداكانه تاثير اين دو بروتكل

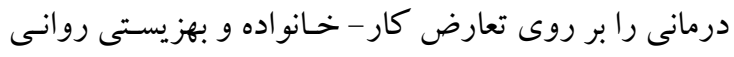

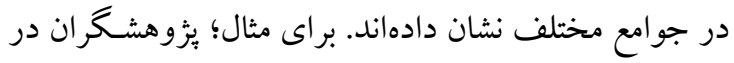
يُزوهشى نشان دادنــ كه زوج درمـانى شـناختى كرفتـارى و درمان مبتنى بر بذيرش و تعهل بـر افزايش شـادى زناشـويى

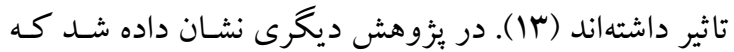
مداخلات مبتنى بر واقعيتدرمانى بـر ابعاد كيفيت زنـدكى كاركنان بـه طور معنـادارى تأثير دارد (f) (I). در مطالعهاى محققان به اين نتيجه رسيدند كه در گروه آزمايشى تركيبى

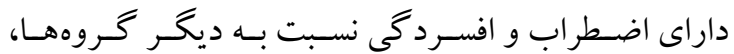

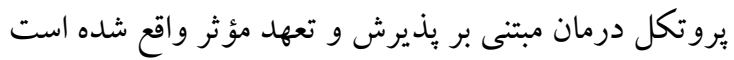

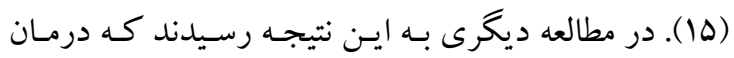

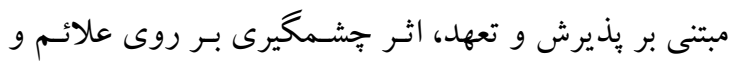

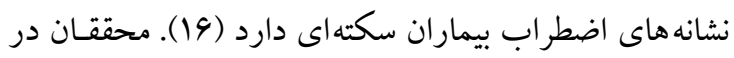
طى بثروهشى به اين نتيجه رسيدند كـه معنادرمانى و درمـان

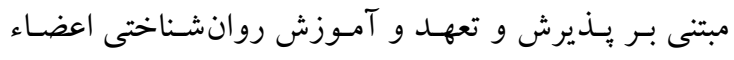

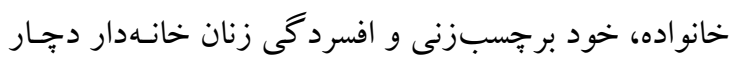

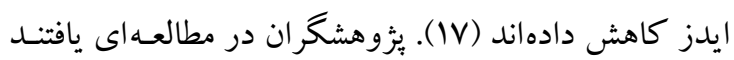
كه آموزش واقعيت درمانى مبتنى بر نظريـه انتخـاب بـر روى دهـ

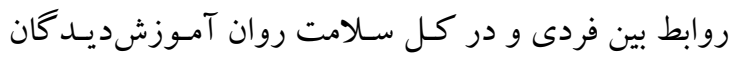

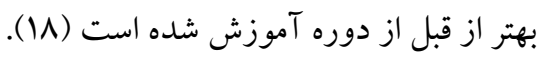

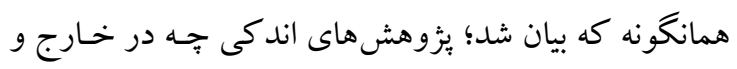

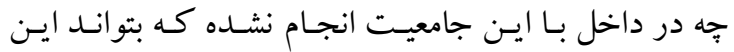
متغيرها را يوشش دهد و همين موضوع يكى از دلايل انجام اين ئزوهش بود. از سويى؛ وجود رابطه بين هركـدام از ايـن

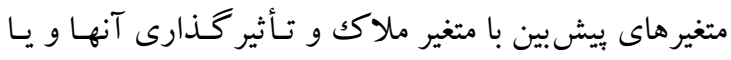

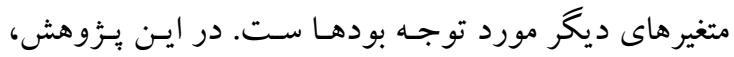
محقق به دنبال باسخكويى به اين سئوال مىباشد كه آيا بين

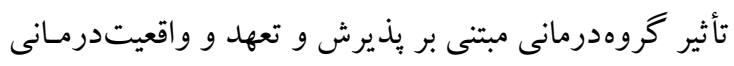

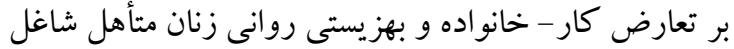
در شركت مخابرات تفاوت وجود دارد؟. 


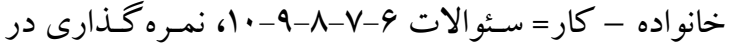
اين يرسشنامه بـر اسـاس مقيـاس هفـت درجـهاى ليكـرت از "كاملا مخالف" تـا "كـاملا موافق " اسـت. نمـره بيشتر بـهـ معناى تعارض بيشتر است. بايايى برسشـنامه از روش آلفـاى

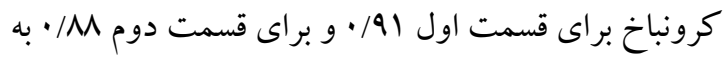
دسـت آمـده اسـت. روايسى ثرسشـنامه توسط سـازند كان يرسشنامه به روش همبستخى هر دو قسمت آن بـا 19 سـازه

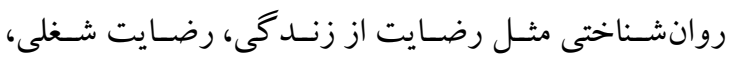

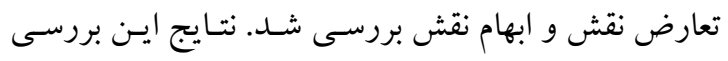

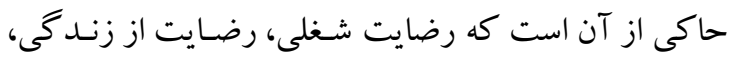

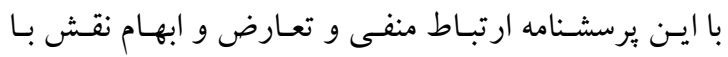

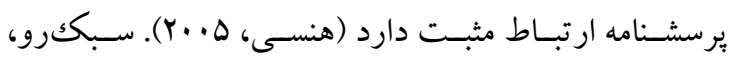

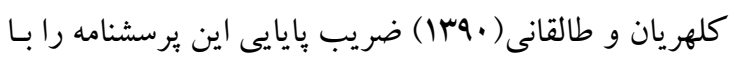

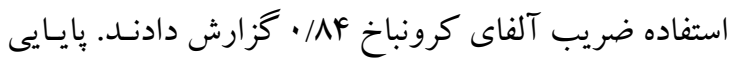
مقياس در يزوهش افتخار صعادى و باوى (ITAY) با استفاده

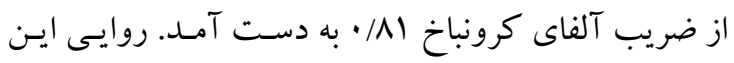

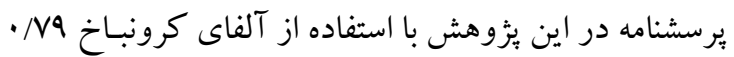
كزارش شد. جهت اجراى يزوهش، كليه آزمودنىها قبل و بعد از اجراى

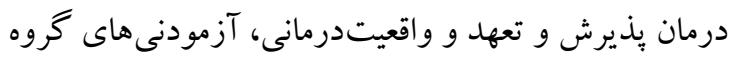

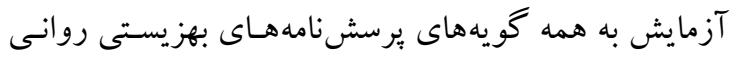
(ريف، 1919) و تعارض كار - خانواده (لذنت و همكاران،

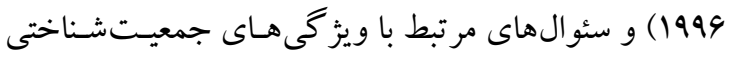
پاسخ دادند. يُوهشخر نيز متعهد شد كه براى رعايت اصول

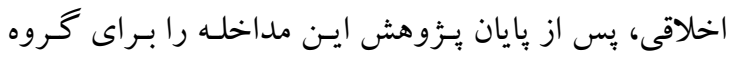
كنترل نيز انجام دهد.
عامـل Fا سـو ال اختصـاص يافته اسـت. ايـن عوامـل شـامل

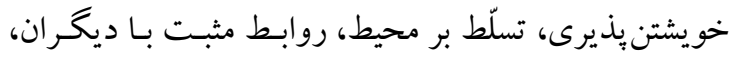
رشد شخصى، هدف در زندگى و خود ويروى هستند. ضمن برن اين كه مجموع نمر ات اين شش عامل نيز بـه صسورت نمـره كلى بهزيستى روانى محاسبه مى شود (ريـف و كيز 1990). در ايران، بيانى و همكاران (IFAV ) روايى و بايايى نسخه سئو الى را روى نمونهاى از دانشجويان بررسى كردند. بايايى از طريق باز آزمايى، ضريب به دست آمده براى نمره كلى را

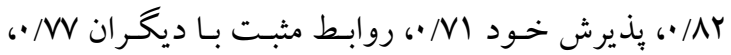
خودييروى /VN/، تسلط بـر محيط /VV/•، هـدفمنـى در

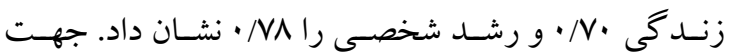

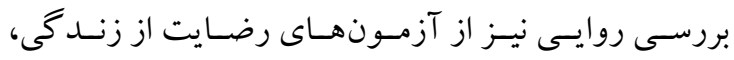

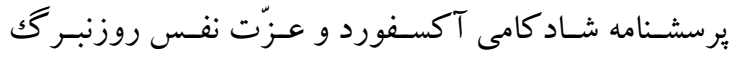

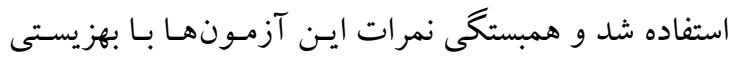

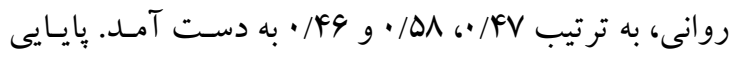
اين برسشنامه در اين يثزوهش با استفاده از آلفـاى كرونبـاخ

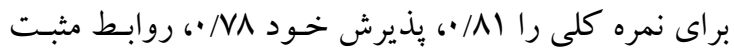

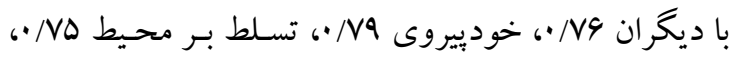

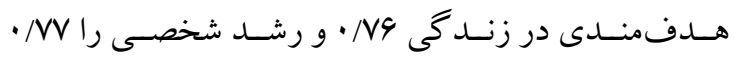

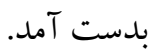
يرسشنامه تعارض كار - خانواده (نت ماير، برلز و مـك- بلـ ماريان، 1999) اين برسشنامه توسط نت ميرز، برلزز و مـك ماريـان (1999)

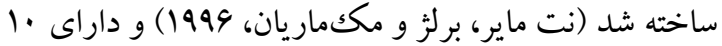
سئوال است كه ينج سئو ال اول آن تعارض كار - خـانواده و

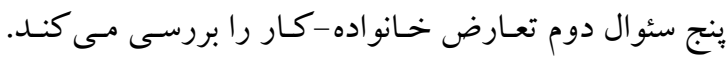

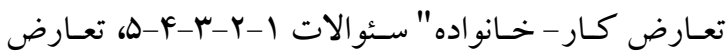


جدول ا: محتو اى جلسات درمان مبتنى بر يذيرش و تعهد

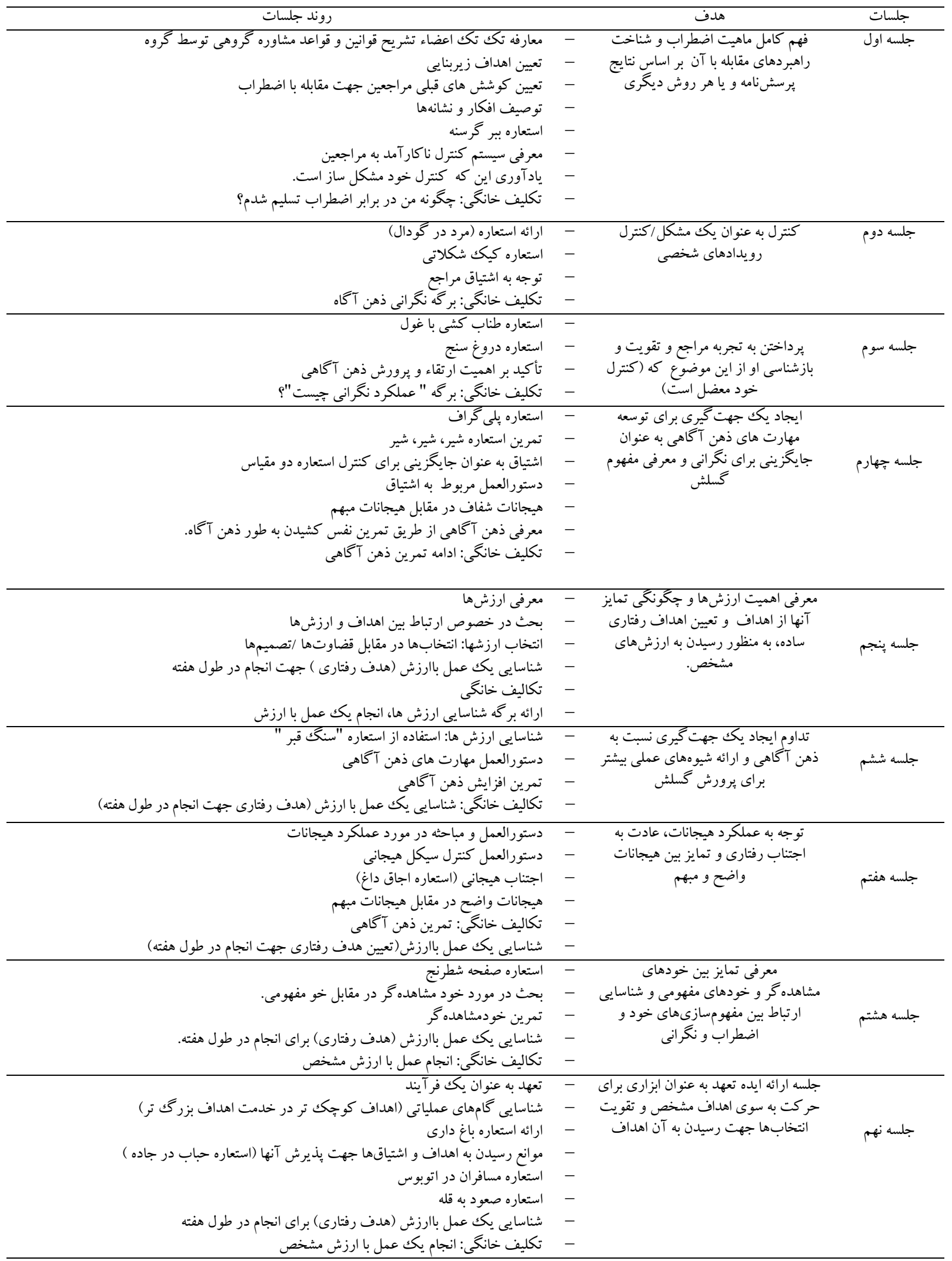




\begin{tabular}{|c|c|}
\hline شرح & جلسه \\
\hline 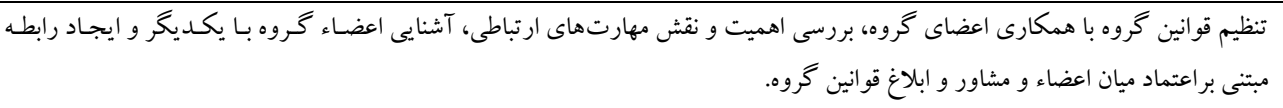 & جلسه اول \\
\hline شناختن ه نياز اساسى انسان، فهرست بندى نيازهاى اساسى اعضاء با تلاش خود آنها و كمكك مشاور و بررسى اهميت بر آوردن اين نيازها. & جلسه دوم \\
\hline 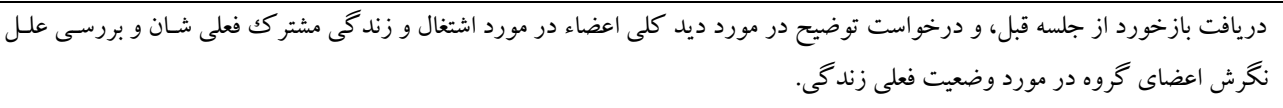 & 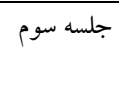 \\
\hline 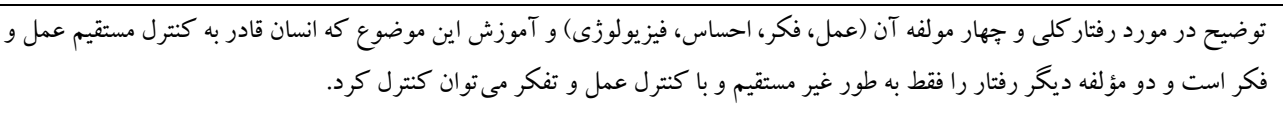 & جلسه جهارم \\
\hline تعبين ميزان دسترسى يا نا كامى اعضاى كُروه در استفاده از رفتار و اقدام كنونى براى اشتغال و بررسى اينكه رفتار فعلى شـان بـراى رسيدن & جلسه ينجم \\
\hline تأكريد بركت بازخول درد از جلسه نسبت به اشتغال. مكك به اعضا براى شناختن رفتار و احساس كنونى شان، و كم اهميت جلوه دادن كذشته در رفتار كنونى و & جلسه ششم \\
\hline 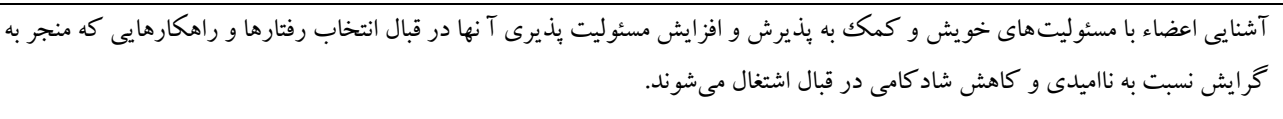 & جلسه هفتم \\
\hline 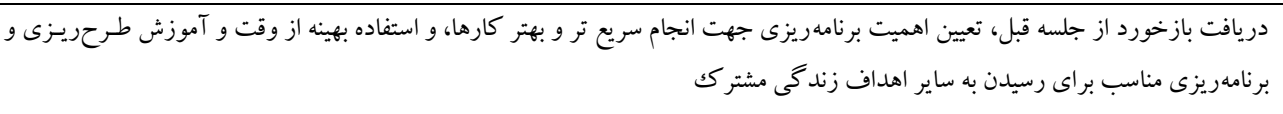 & جلسه هشتم \\
\hline 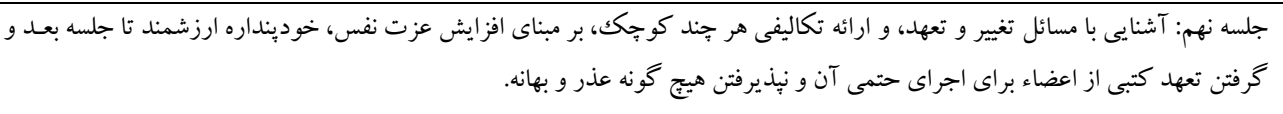 & جلسه نهم \\
\hline 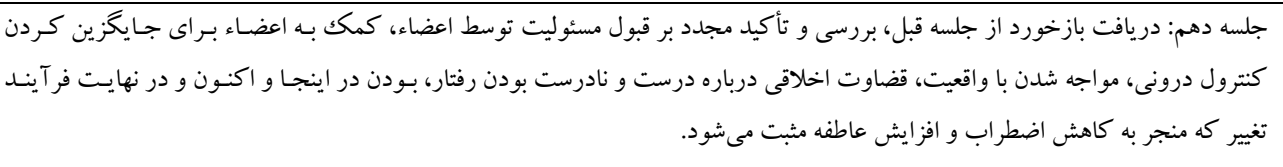 & 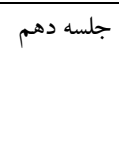 \\
\hline
\end{tabular}

كروه كنترل rV/r با انحر اف استاندارد F/ F/ بود كه دامنه

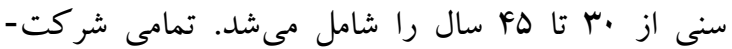
كند كان اين يُزوهش، كار كنان زن متأهل شركت مخابرات منطقه تهران بودند (جدول r). ميانگين و انحراف استاندارد متغيرهاى مورد مطالعه را در بيش آزمون، بِ بـ آزمون و بيى كيرى بعد از دو ماه مداخلات را نشان مىدهد.

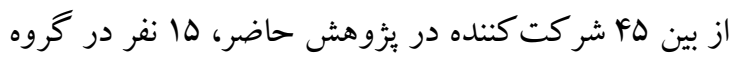
درمان بذيرش و تعهد، 10 نفر در خروه واقعيتدرمانى و 10

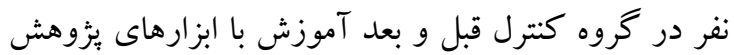

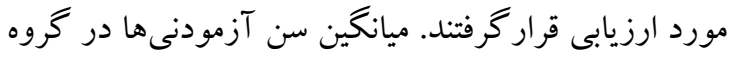
درمان يذيرش و تعهد TV/T با انحراف استاندارد FV

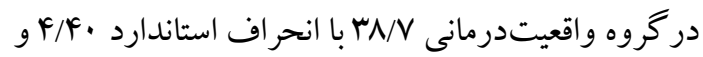


جدول "َ: ميانكين، انحر اف استاندارد براى نمرات متغيرهاى يزوهش در بيش آزمون و يس آزمون

\begin{tabular}{|c|c|c|c|c|c|c|c|}
\hline \multicolumn{2}{|c|}{ كنترل } & \multicolumn{2}{|c|}{ واقعيت درمانى } & \multicolumn{2}{|c|}{ تعهد و يذيرش } & \multirow{2}{*}{ آزمون } & \multirow{2}{*}{ متغير ها } \\
\hline انحر اف استاندارد & ميانخين & انحر اف استاندارد & ميانخين & انحر اف استاندارد & ميانگين & & \\
\hline$r / \cdot \wedge l$ & $491 \cdot \mathrm{V}$ & 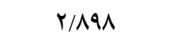 & $90 / 4$. & $1 / 140$ & $99 / 4 V$ & ي بيش آزمون & \multirow{3}{*}{ تعارض كار - خانو اده } \\
\hline$r / 49 q$ & $90 / \pi r$ & $r / 9 q$. & $01 / 9 \pi$ & F/ard & $\Delta F / Q T$ & پِس آزمون & \\
\hline $1 / 911$ & $90 / \cdot V$ & $r / 991$ & $\Delta 9 / 1 T$ & $\Delta / V \mu$. & $91 / 4 V$ & يِيخيرى & \\
\hline $\mathrm{rr} / \mathrm{IVq}$ & raY/A. & YI/DVY & $r F q / V T$ & $r \cdot / 1 r^{\prime}$ & $r \Delta F / Y$. & ييش آزمون & \multirow{3}{*}{ بهزيستى روانى } \\
\hline$r q / \cdot \wedge q$ & raY/A. & $19 / 94$. & $\mathrm{raq} / \mathrm{A}$. & $r \Delta / A \cdot F$ & TVN/FV & يس آزمون & \\
\hline Y9/191 & raf/m & YI/TAV & $M F F / I \mu$ & YF/MFA & $\mathrm{rol} / 9 \mathrm{~V}$ & يِيخيرى & \\
\hline
\end{tabular}

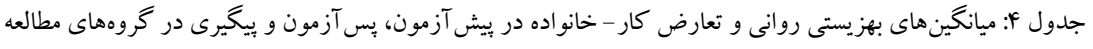

\begin{tabular}{|c|c|c|c|c|}
\hline ييخيرى & يس آزمون & & & كروههاى مطالعه \\
\hline SV/TDI & FV/RVA & $r \cdot / r \Delta F$ & ميانگين & تعهد و يذيرش \\
\hline MFN/YF & $\Lambda \cdot F / r \Delta$ & $1 r q / r$. & انحراف معيار & \\
\hline Ir/MFF & $1 \cdot / \pi 99$ & $V M / Y F q$ & & واقعيت درمانى \\
\hline rAV/rI & $94 \cdot / 19$ & $\Delta V Y / r I$ & انحراف معيار & \\
\hline MT/raf & $\Lambda \cdot /$ rar & $\Lambda \cdot / r q$. & & كنترل \\
\hline $191 / 79$ & $\cdot 19 / 49$ & IVa/rT & انحر اف معيار & \\
\hline ( & . Y/MFV & $91 /$ KGF & & كل \\
\hline$\Delta \wedge 9 / \Gamma \Delta$ & $\cdot 1 \Delta / \& 4$ & $\Lambda 9 \Delta / \mu$. & انحراف معيار & \\
\hline$F V / 91$ & $q \mu / \Delta F$ & $\mathrm{FV} / 94$ & & تعهد و يذيرش \\
\hline$V r / \Delta$ & $q r / 4$ & $\Lambda \Lambda \Delta / \Lambda$ & انحراف معيار & \\
\hline $1 \% / 09$ & $94 / D 1$ & $4 \cdot 190$ & & واقعيت درمانى \\
\hline $99 / \Gamma$ & $99 / \%$ & $\Lambda 9 \Lambda / r$ & انحراف معيار & \\
\hline$\cdot V / 90$ & $M / 90$ & $\cdot v / 94$ & ميانگين & كنترل \\
\hline $9 / / 1$ & $4 \& / Y$ & $\cdot 11 / \pi$ & انحراف معيار & \\
\hline 19/9. & $F \cdot / \Delta V$ & $91 / 90$ & ميانگين & كل \\
\hline$\Delta Y / \Delta$ & $99 / 9$ & $90 \cdot / r$ & انحراف معيار & \\
\hline
\end{tabular}


جدول ه: نتايج تحليل اندازهيرى تكرارى و آزمون بين گروهى نمرههاى بهزيستى روانى و تعارض كار - خانو اده در گروههاى مو رد مطالعه

\begin{tabular}{|c|c|c|c|c|c|c|c|}
\hline مجذور اتا & سطح معنادارى & 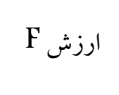 & ميانكين مجذورات & آزادى درجه & مجذموع مجذورات & وضعيت & منبع تغييرات \\
\hline$\cdot / \Lambda \Lambda$ & $\% \cdot \cdot 1$ & $r \mu / r$. & $9 \cdots / 90$ & 1 & $9 \cdots / 90$ & مراحل & برزيست گروانى \\
\hline$\cdot / r q$ & $\% \cdot \cdot 1$ & $1 / V 9$ & $1091 / r \pi$ & r & $r \mid \Lambda r / F \Delta$ & مداخله & بين گروانى بهزيستى \\
\hline \multirow[t]{2}{*}{.$/ 94$} & $\% \cdot \cdot 1$ & $r \cdot \Delta / 9 q$ & . & $r$ & FYVYF/.G & مر احل "*مداخله (***) & تعامل \\
\hline & & & $r \cdot N / 9 V$ & Fr & 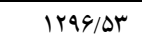 & خطا & \\
\hline.$/ 01$ &.$/ . \cdot 1$ & $r q / r q$ & $\Delta \Lambda Y / 9 V$ & 1 & $\Delta \Lambda Y / Q V$ & مراحل (***) & تعرون گروهى \\
\hline $.19 \mathrm{~V}$ &.$/ .1$ & $F Y / F V$ & $991 / 9$. & r & $I T r V / r$. & مداخله & كار-خ خانواده \\
\hline \multirow[t]{2}{*}{. } &.$/ . \cdot 1$ & $9 / V^{F}$ & ITN/IV & $r$ & rDG/TD & مراحل "*مداخله (**) & تعامل \\
\hline & & & $1 \% / 10$ & Kr & $\Delta \Delta Y / F G$ & خطا & \\
\hline
\end{tabular}

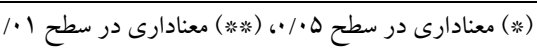

معنادارى وجود ندارد، اما بين هر دو گَروه (گُروه تعهـد و

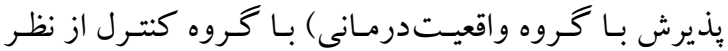
آمارى تفاوت معنادارى وجود دارد. به عبارت ديخر؛ نتـايج نشان دادند كـه گرووهدرمـانى مبتنسى بـر يـذيرش و تعهـد و واقعيت درمانى در ماند گارى افزايش بهزيستى روانى مـؤثر

هستند.

بنابر اين، شواهل بر اى يـذيرش ايسن فرضسيه كـافى اسـت. بـر اساس نتايج به دست آمـده از ايسن فرضسيه تحقيـق مسى تـوان

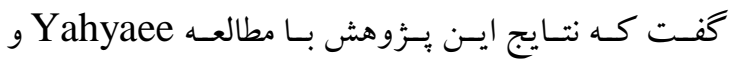

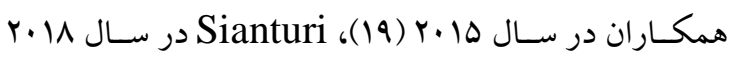

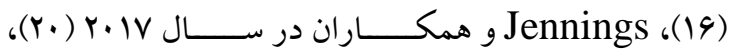
Rasoli Jazani Mohamadi همكاران در سال ها •Y (سץ) و Davis و همكاران در سال تقريباً همخو انى دارد. (YF) Y. IF در نظريه بذيرش و تعهلد درمانى كه اينجا لحاظ شد، به ايـن نكته در سلامت روان تأكيد دارد كـه بـه جـاى آنكـه روى برطرف سازى و حذف عوامـل آسـيبزا تمركز نمايـد، بـه كارمند كمكك مى كند تا هيجانـات و شـناخت هـاى كنتـرل
نتايج به دست آمده از تحليل اندازه گيرى تكرارى و آزمون بـين گروهـى نمـرههـاى بهزيستى روانسى و تعـارض كـار خانواده در گروههاى مطالعه را نشان مىدهد كه در تفـاوت ميان نمرههاى بهزيستى روانى و تعـارض كـار - خـانو اده در بيش آزمون، بس آزمون و بيى گيـرى از نظر آمـارى معنـادار

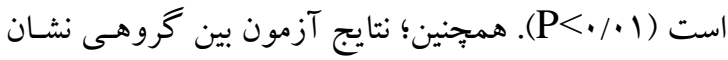
مىدهد كه تفاوت ميان كروهها از نظر آمارى معنادار اسـت

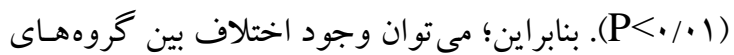
مـورد مطالعـه رادر يسس آزمـون و يسى گيـرى در نمـرههـاى بهزيستى روانى و تعارض كار - خانو اده را يذيرفت.

هدف اين مطالعه بررسى مقايسهاى اثربخشى گَروودرمـانى مبتنسى بـر بـــيرش و تعهــ (ACT) و واقعيـتدرمـانى بـر

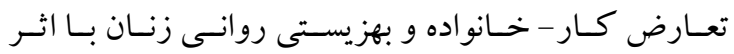
ماندكارى بود. جهـت آزمـون فرضـيههـاى ايـن يـزو هش از تحليـل واريـانس جنــ متغيـره اسـتفاده شـــ. طبـق نتـايج بـه دست آمده، در بهزيستى روانى بين گروههاى (كروه تعهد و

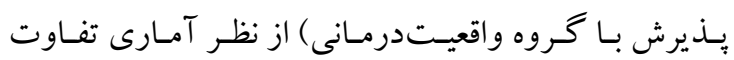


نشان مى دهــ؛ درمـانهـاى تر كيبـ مسى تو اننـد تأثير فوقالعادهاى بر روى افزايش بهزيستى و سـلامت روانشـناختى

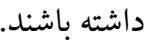
طبق نتايج بهدستآمده از فرضيه ديخر اين مطالعه، در تعارض كار - خانواده بين گروههاى (كروه تعهد و يذيرش با گروه واقعيتدرمانى و كنترل) از نظر آمارى تفاوت وجود دارد. به عبارت ديخر؛ نتايج نشان دادند كه كرومدرمانى مبتنى بر خذيرش و تعهد و واقعيتدرمانى در ماندكارى كاهش تعارض كار - خانواده زنان متأهل شاغل مؤثر هستند. اما اثر خروه واقعيتدرمانى بيشتر از خروه تعهد و بذيرش است. بنابراين، شواهل براى بذيرش اين فرضيه

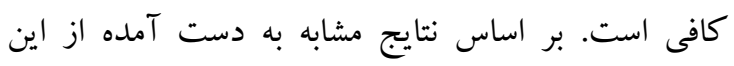

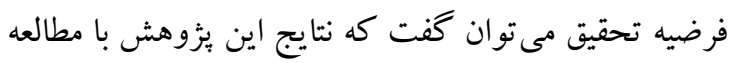
Ramzi

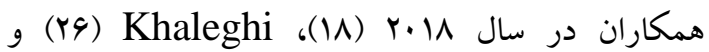

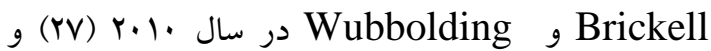

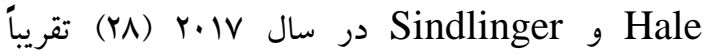
همخوانى دارد. درمان مبتنى بذيرش و تعهد؛ ارزشها را به عنوان كيفيتهاى انتخاب شده اعمال هدفمندانه جهت حل

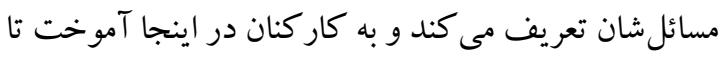
بين انتخاب و قضاوتهاى مستدل تمايز قائل شوند و ارزشها را انتخاب نمايند.

به كار كنان كفتـه شـد تـا آنجـهـ را از زنـدكى شـغلى خـود

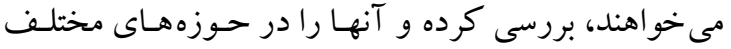

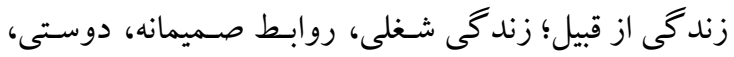
رشد شخصى، سلامتى و معنويت مدنظر قرار دهنــ. امـا در واقعيت درمانى به كارمند آمـوزش داده شـد كـه تمـامى راه حل هاى حل مسئله و مشكلات شغلى را بنويسد و سبِّ بـه تجزيه و تحليل راه حل هاى بيشنهادى بيردازد. تـا بتوانتـد از

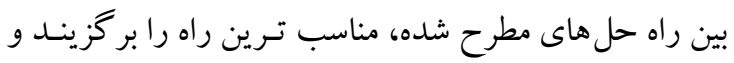

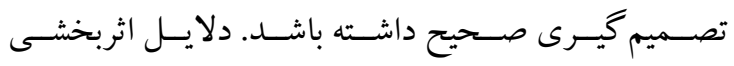
واقعيت درمانى در تعارض كار - خانواده، مربوط به تغييرات شناختى ناشى از اين راهبرد درمانى است. واقعيت درمانى بـه

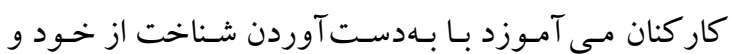

شده خود را در محيط كسارى يذيرفتهه و خـود را از كنتـرل قوانين كلامى كـه سبب ايجـاد مشكلاتشـان كرديـده، خلاص نمايد و به آنها اجازه مسىدهـد كـه از كشـمكث و منازعه با آنها دست بردارند. مى توان بيان كرد كه بهزيستى روانشناختى زمانى بهوجود مى آيد كه كارمند خود را دليل

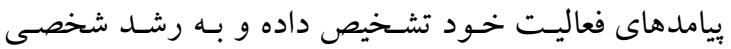
برسد. يعنى براى رسيدن به سطوح بالاى عملكرد روانى بايد به صورت بيوسته در جنبههاى متفاوتى از زندگى رشد كند. در واقع؛ كارمند به طور مداوم در كارها در گير مى شوند تـا مشكلات را حل كنند تـا بـه موجـب آن توانايى هايشـان را كسترش دهند. تسلط بر محيط به معناى تو انايى كارمند براى مديريت زندگى شغلى وى است. با اين توصيف فردى كـه حس تسلط بر محيط دارد، مى تواند در جنبهه هـاى مختلف

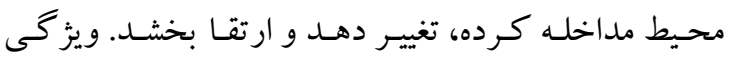

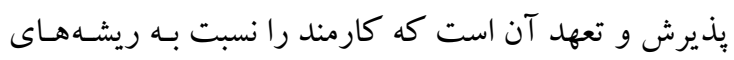

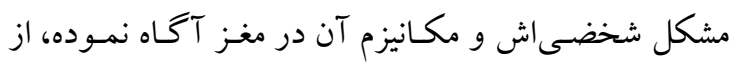

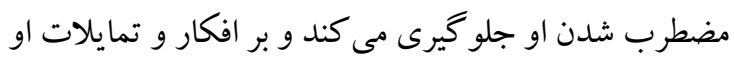

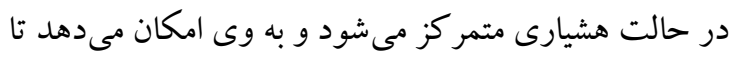

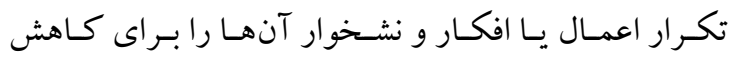
تعارض كار - خانو اده انتخاب نكند و بـه ريشـهـهـاى زيستى ونس

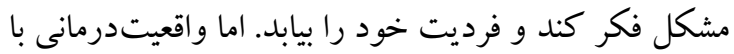

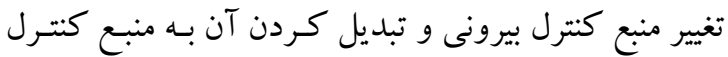
درونى به كار كنان مى آموزد كه خوشبختى و موفقيت آينده آنها نه در اتفاقات كذشـته شـغلى اسـت، بلكه در دسـتان خود آنهاست و آنها مى توانند آينده شغلى خود را همان ان الهان كونه كه دوست دارند رقم بزنند.

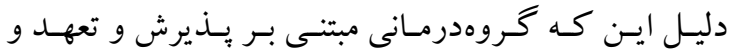
واقعيتدرمانى در بهزيستى روانى زنـان متأهـل شـاغل اثر ماند گار داشتهاند اين است كه مولفههاى هر دو بروتكل در جلسـات تعيسين شـده داراى سـاختارها و مفـاهيم بهداشـت روانى بوده كه مىتواند بهزيستى روانشناختى را بالا بـرده و حتى تداوم در طول زمـان داشـته باشـند. نتـايج ايـن فرضيه

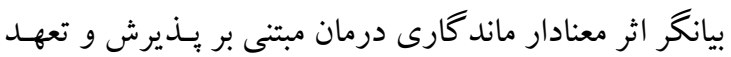

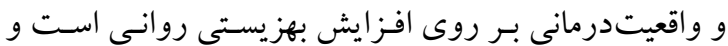




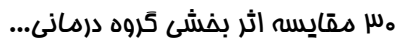

در اين راستا؛ بـهنظـر مسىرسـد درمـان مبتنى بـر يـذيرش و تعهــد بـا ترغيـب افـراد بـه تمـرين مكــرر توجـهـ متمركـز

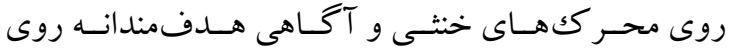
جســم و ذهــن، افــراد اضـطر ابى را از اشـتغال ذهنـى بــا

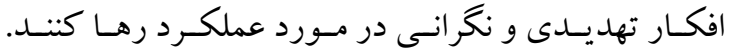
يعنى اين فنـون بـا افزايش آكَاهى فرد از تجربيـات لحظه.

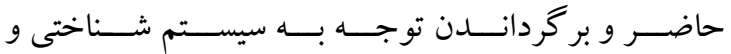
يسردازش كار آمــدتر اطلاعــات، موجسب كــاهش نكرانسى و تسـش فيزيولوزيــك در فــــد مــى گــــدد. در الخَــوى درمـانى واقعيـت درمـانى بــه افـراد آمسوزش داده مسى شـود

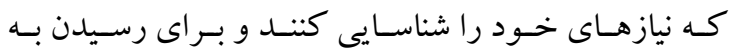
نيازها و دسـتيابى بـه هـــف هـاى شـان برنامـه هـاى مسـئولانه تهيـهـ و اجـــا كنــــ. وقتـى كـه نيازهــاى فـرد شــاخته و تـأمين شـود، باعـث احسـاس كفايست شخصسى در محسل كـار و بــه تبـع آن كـاهش احســاس مســخ شخصـيت و خستخى هيجـانى و تعـارض كـار - خـانو اده مسىشـود. بــه عبارتى؛ موجب افزايش بهزيستى روانى مى گردد.

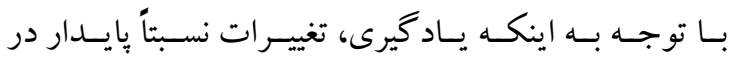

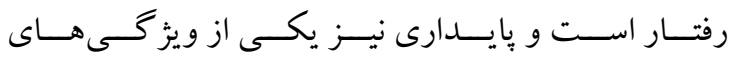

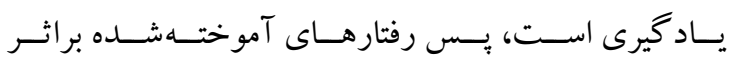

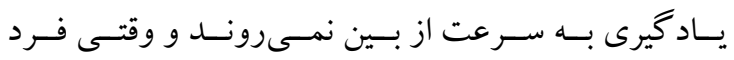
مهارت تصسميم گيسرى صسحيح را آموخـت و تجـاربش را

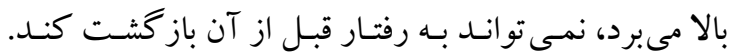

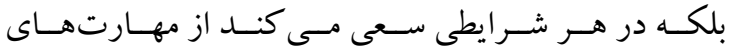
آموخته شده بهـره بخيـرد. لـذا طبيعى اسـت كـه نتـايج بـه -

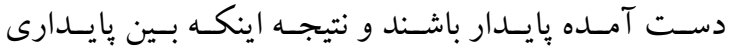

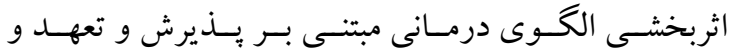
واقعيـتـدرمــانى برافـزايش بهزيســـى روانسى و كــاهش تعــارض كــار - خــانو اده در طــول زمــان وجـــود دارد.

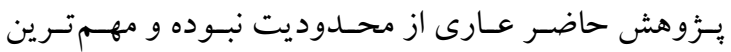
آنهـا محسـدودبودن جامعسه تحقيـق بـه جامعسه كار كنـان زن شـركت مخـابرات شـهر تهـران بـود كـهـه در نتيجـهـ امكـان

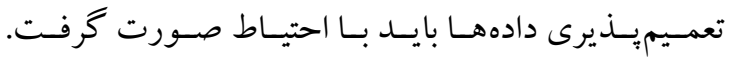

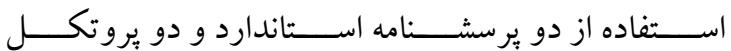

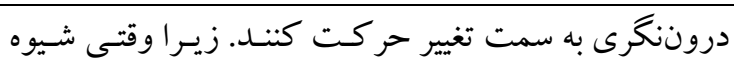
زندكى يـك نو اخـت (شـغلى) بـهـ قـدر كـافى عميـق باشـد، مسى توانــد بـه يـك دور نـامطلوب تبـــيل شـود. از طرفى؟ كروهدرمانى مبتنى بر واقعيت درمانى در مانـد گارى كـاهش تعـارض كــار - خـانواده زنــان متأهــل شـاغل مـؤثر تر از كروهدرمانى يذيرش و تعهد مىباشد به اين دليـل اسـت كـه درمان يذيرش و تعهد افر اد را مجبور مى كند كه فرد خود را مشاهده كند و با خود واقعى اش مواجه شود و اين امر باعث وحشت و استفاده از مكانيسم فـرار مسى شـود. بـهمــين دليـل مشار كت كنــــان بـهـ طـور ناهوشـيار تـرجيح مسىدهنــ در مقابل آن مقاومت كنند و خود را نِذيرنـد و از آنجـايى كـه واقعيت درمانى بر روى عمل افراد متمركز است و فـرد را بـه برنامهريزى سريع وا مى دارد، يذيرش و اجراى آن آسان تر بهنظر مىرسد. نتايج اين فرضيه بيانگكر اثر مانـدگارى درمـان مبتنى بر بذيرش و تعهل و واقعيـتدرمـانى بـر روى كـاهش

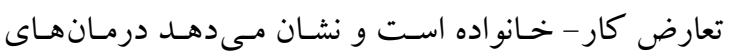
تر كيبى مى تواند تأثير فوقالعادهاى بر روى كاهش تعسارض كار - خانواده و يا هر نوع تعارضى از اين قبيل داشته باشند.

\section{نتيجه تيرى}

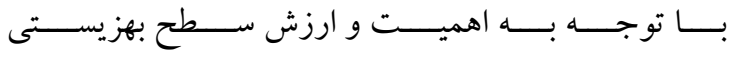

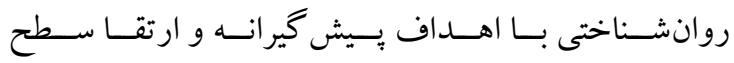

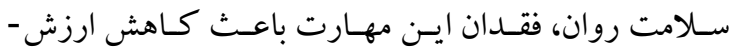
منــدى در فــرد خواهـــ شــد. در نتيجــهـ آمـوزش جنــين مهـارت هـايى در كار كنـان سـازمانهـا احسـاس كفايست، توانيى مؤثربودن، غلبـه كردن بـر مشـكل يـا سـاز كارى بـا ناكـامى و افـزايش عـزت نفـس، توانـايى برنامـهريـزى و رفتار هدف مند و يـا تغييـر اهــاف مواجـه شـده بـا ناكـامى و متناسـب بـا مشـكل را بـهوجـود مسى آورد. داشـتن دركك روشـنى از هــدف در زنــدكى، احسـاس جهــت يـابى و هـدف منــدى بايسه سـلامت روانسى بـهــمار مسىرود، ايسن مقياس نيز بـه كمـك ويز كى هـايى مانــد احسـاس هـدف -

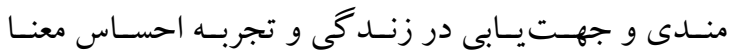
در زندكى كذشته و حال مشخص مىشود. 


\section{Reference}

1. Derks D, Bakker AB, Peters P, Van Wingerden P. Work-related smartphone use, workfamily conflict and family role performance: The role of segmentation preference. Human Relations 2016;69:1045-68.

2. Kelly EL, Moen P, Oakes JM, Fan W, Okechukwu C, Davis KD, et al. Changing work and work-family conflict: Evidence from the work, family, and health network. Am Sociol Rev 2014;79:485-516.

3. Bennett M, Beehr TA, Ivanitskaya LV, Cooper A. Work Family Conflict: Differences across Generations and Life Cycle Stages. J Manag Psychol 2016; 32:314-32.

4. Mansour S, Mansour S, Tremblay DG, Tremblay DG. Workload, generic and work-family specific social supports and job stress: Mediating role of work-family and family-work conflict. Int J Contemp Hosp M 2016;28:1778-804.

5. Burke RJ, Koyuncu M, Fiksenb L. Antecedents and consequences of work-family conflict and family-work conflict among frontline employees in Turkish hotels. IUP Journal of Management Research 2013;12:39-48.

6. Stewart LM. Family care responsibilities and employment: Exploring the impact of type of family care on work-family and family-work conflict. JFI 2013;34:113-38.

7. Nie Y, Chua BL, Yeung AS, Ryan RM, Chan WY. The importance of autonomy support and the mediating role of work motivation for well being: Testing self determination theory in a Chinese work organization. Int J Psychol 2015;1;50:245-55.

8. Blackie, LER, Roepke, AM, Forgeard MJC, Jayawickreme E, Fleeson W. Act well to be well: The promise of changing personality states to promote well-being. In: Parks AC, Schueller SM, Editors. The Wiley Blackwell handbook of positive psychological interventions. Wiley-Blackwell, 2014: 462-74).

9. Ryan LH. Subjective Well Being. The Encyclopedia of Adulthood and Aging. WileyBlackwell. 2015:1003-21.

10. Hayes SC, Strosahl KD, Wilson KG. Acceptance and commitment therapy: an experiential approach to behavior change. New York: Guilford Press, 2009: 231-48.

11. Hayes SC. Acceptance and commitment therapy, relational frame theory, and the third wave of behavioral and cognitive therapies. Behav Ther 2004;35:639-65. 


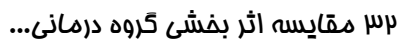

12. Farmani F, Taghavi H, Fatemi A, Safavi S. The efficacy of group reality therapy on reducing stress, anxiety and depression in patients with Multiple Sclerosis (MS). IJABS journals 2015;2:33-8.

13. Azimifar S, Fatehizade M, Bahrami F, Ahmadi A, Abedi A. Comparing the effects of cognitive-behavioral couple therapy and acceptance and commitment therapy on marital happiness of dissatisfied couples in isfahan: a single subject research. Shenakht J Psycholo Psychiatry 2016;3:56-81. [In Persian]

14. Alla Tvakoli Rozbahani H, Heydari H, Davoodi H. The effectiveness of Reality Therapy Group on Psychological quality of life of the Didan conference participants in Kalame Zendeh research center. Forth international conference recent innovation in psychology, counselling \& behavioral sciences. 2017 Jul, 13, Tehran: Iran. [In Persian]

15. Heydari M, Masafi S, Jafari M, Hassan Saadat S, Shahyad S. Effectiveness of acceptance and commitment therapy on anxiety and depression of razi psychiatric center staff. Open Access Maced J Med Sci 2018;6:410-15.

16. Sianturi R, Keliat BA, Wardani IY. The effectiveness of acceptance and commitment therapy on anxiety in clients with stroke. Enfermería Clínica 2018;28:94-7.

17. Suyanti Titi S, Keliat Budi A, Daulima Novy HC. Effect of logo-therapy, acceptance, commitment therapy, family psychoeducation on self-stigma, and depression on housewives living with HIV/AIDS. Enferm Clin 2018;28:98-101.

18. Lojk L, Butorac D, Posavec M, Maras T, Kranželić V, Baković A. Reality therapy training efficiency in helping participants to better their relationships \& improve their psychological wellbeing. International Journal of Choice Theory and Reality Therapy 2018; 31:111-21.

19. Yahyaee GA, Nooranipoor R, Shafiabadi A, Farzad V. The Effectiveness of Reality Therapy on the Improvement of Couples' Family Functioning. Arch Hyg Sci 2015;4:120-7.

20. Jennings T, Flaxman PE, Egdell K, Pestell S, Whipday E, Herbert A. A resilience training programme to improve nurses' mental health. Nursing Times Online 2017;113:22-6.

21. Rasoli Jazani F, Arefi M. Effectiveness of reality therapy group on happiness of mothers with children with learning disabilities. Third global conference on psychology and educational sciences, law and social sciences at the beginning of third millennium, 2016 Nov, 10, Shiraz, Iran. [In Persian]

22. Mohamadi H, Keshavarzi F, Farzad V, Salehi M. Effectivness of acceptane and commitment therapy (act) on marital satisfaction on depressive women with marital conflicts. Knowledge \& Research in Applied Psychology 2015;17:26-35. [In Persian]

23. Rehm I, Moulding R, Nedeljkovic M. Psychological treatments for trichotillomania: Update and future directions. Australasian Psychiatry 2015;22:365-8.

24. Davis M, Morina N, Powers M, Smits J, Emmelkamp P. A meta-analysis of the efficacy of acceptance and commitment therapy for clinically relevant mental and physical health problems. Psychother Psychosom 2014;84:30-6.

25. Ramzi L, Sepehri Shamloo Z, Ali Pour A, Zare H. The effectiveness of group reality therapy in coping strategies. IIFP 2015;1:19-30. [In Persian]

26. Khaleghi $\mathrm{S}$. The effectiveness of group reality therapy in increasing of happiness \& mental health [dissertation]. Tehran: Shahid Beheshti University; 2010. [In Persian]

27. Wubbolding RE, Brickell J. Counselling with reality therapy. 2nd ed. London: Routledge, 2017: 97-105.

28. Hale V, Sindlinger J. Reenvisioning reflective supervision: a choice theory/ reality therapy application using reflecting teams. International Journal of Choice Theory and Reality Therapy 2017; 31:40-5. 